The Politics of Land, Consent, and Negotiation: Revisiting the Development-Displacement Narratives from Singur in West Bengal

\title{
Ritanjan Das
}

\section{(2) OpenEdition \\ Journals}

Electronic version

URL: http://journals.openedition.org/samaj/4103

DOI: $10.4000 /$ samaj.4103

ISSN: 1960-6060

Publisher

Association pour la recherche sur l'Asie du Sud (ARAS)

\section{Electronic reference}

Ritanjan Das, «The Politics of Land, Consent, and Negotiation: Revisiting the Development-

Displacement Narratives from Singur in West Bengal », South Asia Multidisciplinary Academic Journal

[Online], 13 | 2016, Online since 08 March 2016, connection on 19 April 2019. URL : http://

journals.openedition.org/samaj/4103; DOI : 10.4000/samaj.4103

\section{This text was automatically generated on 19 April 2019}

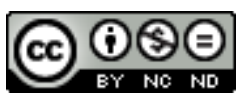

This work is licensed under a Creative Commons Attribution-NonCommercial-NoDerivatives 4.0 International License. 


\title{
The Politics of Land, Consent, and Negotiation: Revisiting the Development-Displacement Narratives from Singur in West Bengal
}

\author{
Ritanjan Das
}

\section{Introduction}

1 With the triumph of capitalism in the post-Cold War era, most countries in the global South embarked on a path of 'transition', initiating economic reforms and attracting foreign investment according to the strictures of global capitalism (Steur \& Das 2009). Particularly interesting amongst such 'transition' cases are countries that explicitly legitimise their rule in terms of communist ideals, the general alliance of peasants and workers toward an egalitarian society, and whose ideological pillars include a pro-poor redistributive land reform (Steur \& Das 2009). This paper highlights one such case in the Indian state of West Bengal, and recounts a story of land struggle and unrest in Singur (a small cluster of villages) between 2006 and 2008, as a thousand acres of prime arable land was forcibly acquired by the government for an automobile factory, much along the trend in contemporary capitalism that David Harvey (2005) conceptualises as the shift in emphasis from expanded reproduction to accumulation by dispossession.

In the face of severe criticism and frequent protests, the Singur project was eventually abandoned. It has attained a cult status amongst activists ever since, being a rare instance of a state government capitulating in the face of peasantry-led protests. However, in the development-displacement narratives of India, Singur was neither the first (an ICSSR study estimates the level of displacement across the country between 1951 and 1990 to be at about 21.3 million), ${ }^{1}$ nor the last (much larger struggles continue to rage in several 
states, for example, around the Posco project in Orissa. See Jenkins et al. 2014 for a detailed discussion on the politics of India's special economic zones).

Nonetheless, the bitter and violent feud at Singur was unique in a different context: it took place in West Bengal, a state ruled by a communist government-the Communist Party of India (Marxist)-CPI(M)-led Left Front coalition-from 1977 to 2011. The coalition was a remarkable instance of political stability, especially in the wider context of caste/religion/ethnicity-based politics and frequent regime changes elsewhere in India (Banerjee 2010). It also brought in significant land reforms, was the first to initiate democratic decentralisation via panchayati-raj (a system of local governance), and gained unprecedented popularity as a government for the poor. Even in the 2006 state elections it earned a historic majority riding on a much-touted industrialisation drive, ${ }^{2}$ but the Singur episode followed immediately afterwards, ${ }^{3}$ and for the first time in over 30 years, the Left Front steadily lost electoral support, eventually relinquishing office in 2011. ${ }^{4}$

Such a dramatic turn of events, where a Left government with a rich history of pro-poor governance suffered rapid electoral decline following the brutalities it unleashed on the peasantry at the apparent behest of a multinational corporation, expectedly, led to a multitude of debates. Questions were particularly raised about (a) procedural inadequacies in the acquisition attempts (hurried acquisition-limited compensation) (P. Banerjee 2006, Sarkar 2007, Chandra 2008); and (b) development model centric debates about whether the state should act as a facilitator for private projects (as opposed to providing infrastructure and/or focusing on public sector initiatives) (Banerjee et al. 2007). In addition, the long-standing criticism of the neoliberal economic order in its reenactment of the $19^{\text {th }}$ century paradigm of industrialisation by expropriating agricultural land-a form of primitive accumulation-was also invoked (Bhaduri 2007, Bhattacharya 2007, Patnaik 2007, Sau 2008). A fourth strand of criticism emerged as well, interrogating the changing class character of the Left regime, from a pro-poor, agriculture/public sector focus to an aggressive facilitator of private industrialisation via forceful acquisition of agricultural land (Mukharji 2009, Bandopadhyay 2006, S. Banerjee 2006, 2008).

5 Diverse as they are, implicit assumptions about the very 'official' nature of the state-one where the government and its institutions are at the helm-are a commonality amongst all these criticisms. It is however important to interrogate assumption of this kind. While (correctly) questioning the role of the state (for example, questioning the acquisition legislation and the compensation amounts, debating the state's role in private projects, criticising the economic model and the development ethos of the state), these debates do not venture to enquire what Harriss-White (2003) calls the 'shadow state'. In her writings on the Indian society and economy, Harriss-White dismisses views of the state that are formalistic, or too focused on statutory responsibilities, and contends that the official part of the state has been hollowed out over the course of the last few decades and replaced by a 'shadow state'.

6 The idea of the shadow state takes root in Harriss-White's analysis of the local state and the informal economy in India, in which she questions the conventional categorisation of an institutional state with juridical boundaries, a market, and a civil society, and argues that no such clear separation exists at local levels. If one looks below the level of a state capital, then there is an economy 'on the edge of-or frankly outside-the ambit of state regulation' with a great deal of disorder (2003: 74). This is precisely where the 'shadow' lies: a vast assemblage of brokers, advisers, political workers, crooks and contractors 
surrounding the 'official state', depriving it of funds, and helping to ensure that it is run in part for the private benefit of some of its employees. The shadow state is not wholly an informal entity, nor are its boundaries entirely separate. The shadow state comes into being

because of the formal State and co-exists with it. It can be defined as that part of the informal, 'real' economy that cannot operate without the particular form taken by the State [...] the 'shadow' State is a part of the actually existing State [...] the real State, including its shadow, is bigger than the formal State, and has a vested interest in the perpetuation of a stricken and porous formal State. (Harriss-White 2003: 89, emphasis in original)

7 Harriss-White admits that while the shadow state is widely visible in India, ${ }^{5}$ it has rarely been used as an analytical framework. However, it will be an important conceptual tool for this paper, as over three decades of Left rule in West Bengal, transactional spaces between the state and the margins can be easily seen as blending into the 'shadow'. Furthermore, discussions on West Bengal have long been focused on the transformation of the $\mathrm{CPI}(\mathrm{M}) / \mathrm{Left}$ Front far beyond the institutional ambit of the formal state, turning into almost a parallel social institution with absolute control over all facets of (particularly rural) society (for example, see Ruud 1994). Particularly notable in this context are Bhattacharyya's concept of party-society $(2001,2009,2010)$, which highlights how the 'party apparatus' came to occupy centre-stage in all forms of state-society transactions, and Roy's notion of 'informality as a mode of governance' (2005), which locates such informality in the functioning of local clubs and mid-level CPI(M) leaders (2002, 2004), and contextualises it with respect to larger development conflicts in India/ South Asia (2009).

8 But surprisingly, though the CPI(M)'s incursion into every realm of the Bengali society has been extensively discussed, the debates around singur lend themselves to a (formal) state vs. peasantry format. There remains a story to be told about the role of local party functionaries in the process, who often acted with a purpose at odds with the declared objectives of industrial development. The objective of this paper is therefore to produce an alternative narrative of the Singur events, by focusing on certain ground-level elements and dynamics that might be described-following Harriss-White-as constituting the 'shadow'. It does not propose to counter, and in fact complements, the three strands of debate around Singur, but brings to the forefront a set of dynamics that has gone largely unnoticed by those debates. The story presented here emerged out of an ethnographic study of Singur conducted by the author as a part of doctoral research in $2009-10,{ }^{6}$ when the conflicts and tensions in the region were highly volatile. The project had been successfully stalled barely a year before, and yet apprehensions about the future were gradually setting in.

9 A broader point also needs to be made here. Amidst rampant industrialisationurbanisation across India (and much of South Asia), 'land' remains a central arbiter of power. As this volume aptly demonstrates, appropriation of land in the name of development/national security and associated struggles is an increasing phenomenon in the subcontinent. Peasant land is cleared for capitalist investments, purportedly aimed at 'industrialisation' and employment creation, but often driven by real estate speculation and elite consumption, accompanied by the creation of huge reserve labour armies (Banerjee-Guha 2008). However, most discussions of land struggles ${ }^{7}$ suffer from what Harriss-White criticizes as too neat a categorization: the 'state', the 'market', and 'civil society', missing much of the local-level dynamics. Recounting the Singur story through 
the lens of the shadow state, this paper thus also tries to make a broader point that the very idea of the 'state' needs to be revaluated while examining land struggles in South Asia, looking beyond the formal ambit of institutions and legislations, and venturing into the uncharted networks that dominate much of the transactions at the grassroots level. The paper is organised as follows: the next section provides a brief summary of the events in Singur; the following section develops a conceptual framework through which to understand the nature of 'shadow' in West Bengal; thereafter, the multiple narratives of political negotiations around Singur are discussed, drawing on evidence collected during the study. The final section presents some concluding remarks.

\section{Revisiting Singur}

Industrial development in West Bengal under the Left Front has been extensively written about (see Dasgupta 1998, Chakravarty \& Bose 2013), and only a brief discussion of the context is necessary here. The Left Front took office in 1977 amidst a stagnating industrial scenario, but the following decades saw even further decline in the state's industrial fortunes, as the government maintained a militant attitude against all forms of private investment. ${ }^{8}$ In 1994, the government came up with a new Policy Statement on Industrial Development, which for the first time signalled a departure in favour of the private sector and foreign investment. However, the industrial scenario post-1994, though improving gradually, continued to remain sluggish. ${ }^{9}$ In 2000, Buddhadeb Bhattacharya succeeded Jyoti Basu as the Chief Minister, and pursued an aggressive industrialisation agenda from the outset. In fact, his push for large scale industrialisation is seen as the decisive factor behind the CPI(M)'s impressive show in two subsequent state elections. ${ }^{10}$ The government now seemed focused on attracting private investment and generating employment through developing industrial parks, townships, special economic zones (SEZs) and so on. Singur was its first flagship project.

\section{The Singur project}

Immediately after its 2006 'industrial development'-led electoral victory, the government started an intensive campaign to win a big-ticket project to catapult the state into the big league of investment destinations. The much coveted 'Nano' project of TATA Motors (a small car with a promised price-tag of Rs. 1 lakh ${ }^{11}$ only) was announced as that elusive ticket, courted with a range of fiscal incentives, most of which were never made public. Amidst much fanfare, the government promised that the Nano project would turn West Bengal into India's next automobile hub (Chandra 2008).

The controversy was sparked by the decision to acquire 997 acres of agricultural land for the factory, as the site chosen was in the agriculturally prosperous town of Singur, approximately $40 \mathrm{~km}$ from the state capital Kolkata. The land was mainly spread across five mouzas ${ }^{12}$-Berabheri, Gopalnagar, Singherbheri, Bajemelia, and Khaserbheri-with marginal/small farmers constituting more than $50 \%$ of the population. There was also a sizeable section (25-30\%) of unregistered sharecroppers and landless people (WBIDC 2006, P. Banerjee 2006). The initial compensation offered was Rs. 8.7 lakhs and Rs. 12.8 lakhs per acre for single-cropped and double-cropped land respectively for landowners; registered sharecroppers were to receive $25 \%$ of this value. 

livelihood. The first organised agitation took place on 25 May 2006, and soon after, a Krishijami Raksha Committee (Save Agricultural Land Committee) was formed, which held its first demonstration on 1 June. Between 9 May and 27 September there were nine meetings between the government and local representatives, including four with the Krishijami Raksha Committee, but they failed to reach a consensus (Mohanty 2007). The protests escalated rapidly, bringing together a motley political coalition spearheaded by the $\mathrm{TMC}^{13}$ under its leader Mamata Banerjee. Their specific demand was to return 400 acres that belonged to unwilling farmers (plot-holders who refused to part with their land and collect compensation, although some were absentee landlords/businessmen) (Sau 2008). The movement received widespread support from civil rights and human rights groups, legal bodies and social activists.

office was surrounded by thousands of protestors demanding the process be stopped. What happened during the following hours remains unclear, but the police finally resorted to a lathi (stick or baton)-charge that resulted in one dead, and several injured. Another phase of violent clashes took place in December, and the government imposed prohibitory orders to continue operations. A ceremonial inauguration of the factory took place on 21 January 2007, with the prohibitory orders still in place.

Construction continued throughout 2007 and the first half of 2008 amidst regular protests and agitations. However, a fresh bout of intense agitation led by Mamata Banerjee in August 2008 brought work to a complete standstill. This led to another series of inconclusive negotiations between the government and the opposition, culminating in a formal withdrawal of the project by TATA Motors, announced on 3 October 2008.

\section{Debates around land acquisition}

Naturally, a wide range of questions emerged about the entire episode (see Nielson 2010 for a comprehensive discussion). There were debates about the high-handed manner of acquisition following an archaic law (the Land Acquisition Act, 1894). The problem was primarily twofold: land pricing and compensation quantum. Estimating adequate market value in a sparse market for agricultural land is rather difficult. Additionally, a small farmer usually self-consumes a proportion of his production, but having parted with his land will be compelled to buy food at market price. Market valuation therefore, even if accurate, fails to provide adequate compensation. Questions were raised about evaluating land price based on earnings from its present use, rather than possible returns from future industrial usage. While it might be deemed appropriate that the present owner should also receive a share of this increased valuation, as per the Land Acquisition Act, 'any increase to the value of the land [...] likely to accrue from the use to which the land acquired will be put' has to be neglected when determining compensation (Sarkar 2007: 1435, emphasis added). Compensation based on the market valuation of land was thus naturally judged insufficient. Furthermore, the compensation package completely ignored inflationary pressures. Once adjusted, the future returns fell ruefully short of even the current monthly income from an acre of multi-cropping land (Sarkar 2007: 1435). 
Not only were these issues widely debated in West Bengal, they also found a national resonance, as the parliament soon enacted a new land acquisition bill. However, amidst wide-ranging discussions about procedural inaccuracies (along with debates about development paradigms and the Left class-character), the intense political nature of the events was hardly emphasised. There remains, outside the dominant criticisms, an undercurrent of 'grass-root politicisation' that has been the cornerstone of West Bengal politics over the last three decades. Much along the lines of the shadow state, West Bengal witnessed the increasing importance of political managers/workers/cadres during the Left rule, and true power, especially in the countryside, rested squarely with them. This can be described as the functioning of an alternative bureaucracy, which-while operating in the shadow of the state-did not just coexist with the latter, but enjoyed almost absolute control over all its institutions. The next section develops this concept further.

\section{The shadow state in West Bengal: the CPI(M)'s alternative bureaucracy}

Political discourses built around the Left Front during its first fifteen years remained dominated by (mostly positive) accounts of its institutional initiatives (see Kohli 1987, 1990). Debates and criticisms, though increasingly forthcoming, were restricted to methodological aspects, without providing any alternative intellectual hypothesis.

It was only in the late 1990s that a new line of argument emerged, focusing on a culture of political mediation embedded in the operational character of the CPI(M). It was not in governance or ideology, but rather in the party's 'mediation between the government and the population in a field of popular transactions that the regime's durability lay' (Bhattacharyya 2009: 60). Well-orchestrated party machinery was not a governance channel, but an instrument for mediation aimed at strengthening electoral position.

During the Left rule, transactional spaces between the state and society in West Bengal gradually came to be dominated by one single form-political allegiance and association. Here no negotiation was allowed, or even recognised, unless it was backed by a recognisable party allegiance or had a distinct party identity of its own. So entrenched was this practice in the political culture of the state, as it still is today, that all parties, irrespective of size or strength, were compelled to conform to it. It was, however, the Left parties-especially the CPI(M)-that were most successful in their 'day-to-day management of the [...] society with the help of a well-orchestrated, locally-embedded and vertically-connected party-machinery' (Bhattacharyya 2009: 60).

In practice, this 'day-to-day management' took the form of the CPI(M) entrusting a network of well-disciplined party cadres with the task of overseeing implementation of all governance initiatives. However, over time, the overwhelming presence of party cadres did not remain restricted to monitoring governance initiatives alone, as local figureheads started to extend their custodianship into every aspect of rural social life: from private affairs such as marrying one's daughter (the party might question the choice of groom depending on political allegiance), to family feuds (property affairs), building a house (choice of contractor), and social/administrative issues such as procuring a ration card (which was much quicker if one belonged to the 'correct' party). Local clubs, cultural associations, and even schools and colleges were brought under the political umbrella as 
the party began to enjoy the last word in all matters of right and wrong within local communities. ${ }^{14}$

This is precisely how the shadow state took shape in West Bengal. With a vast assemblage of party-cadres overseeing most forms of social transactions, there was rapid erosion in state institutions' legitimacy, as they could hardly function without the approval of the 'shadow' (party functionaries), with the latter enjoying the tacit support of the former to ensure electoral support. Entrusted by the party leadership with the task of fostering political allegiance, these local chieftains quickly became the sole benefactors of rural socio-political lives, carefully monitoring the political returns of all governance initiatives. Some of these party functionaries were panchayat members or bureaucrats in block development offices; others could be party local/block/district committee members. In effect, the CPI(M) had created an entire parallel structure to supervise and control crucial state institutions, as well as to monitor the provision of even the most basic civic services with an eye to upholding partisan motives.

A parallel phenomenon reinforced this development. While West Bengal was routinely criticised for bureaucratic inefficiency, historically, given the level of party-supervision, it was rare that administrative decisions, particularly below state level, could be taken without political approval. In effect, formal administrative channels not only suffered from partisan incursions, but also became heavily dependent on political leadership for normal functioning..$^{15}$ Therefore, while the rhetoric emanating from the top government offices post-1994 promised a transition in industrial policy, political control over the process was barely relinquished. Adjustments were only made to the extent that would suit localised political priorities. As a result, in spite of some attempts to bring the new economic priorities to the forefront, the transition could hardly generate the intended impact. With an almost defunct channel of administration, having lost the capability to perform autonomously, real control of the process shifted back to party quarters (in the 'shadow'), and implementation exercises became an opportunity to maximise local political interests.

What this meant was that the government was reliant on party networks even for daily administrative purposes. While this is certainly not a unique phenomenon, the Left Front stands apart due to the degree of this reliance, which in all senses was absolute. Another factor that sets West Bengal apart was the ideological legitimisation of such dependence, routinely provided by party heads (see the Anil Biswas quotation below). From assessing ground-level priorities to formulating policy decisions and implementation, the party's parallel structure was in charge. This structure was analogous to an alternative bureaucracy-owned and controlled by the party-working primarily to maximise political interests by virtue of its authority over formal administrative services. The idea of an alternative bureaucracy does not indicate that it replaced state bureaucracy, but that at every stage of formal administrative processes there was a parallel party authority, providing political supervision and vetoing administrative decisions based on political mileage (for example, party local, zonal and district committees would oversee panchayats (village or supra-village councils) at the village, samiti (regional), and zilla (district) levels respectively. See $\mathrm{H}$. Bhattacharyya 1998 for a detailed discussion). It would also act as a more reliable source of ground-level information, or at least filter formal information sources as 'politically appropriate'.

This was certainly not an unexpected development. Controlling various administrative units was a declared political-ideological goal of the CPI(M). Anil Biswas, ex-CPI(M) 
Secretary and Left Front Chairman, explained in a 2001 interview (with The Statesman) that the government and the party remained in a symbiotic relationship, and went on to assert that a true Marxist gladly follows the party diktat and is proud to be a 'puppet in the hands of the party'. ${ }^{16}$ Given this attitude, it is hardly surprising that the government, instead of using its official channels for administration, started to rely on the party's own people or own sources.

The alternative bureaucratic structure gave rise to some key area-specific political managers or party supremos, who oversaw all operations in their localities/districts. Some, who operated on the fringes of Kolkata, were established mid-level CPI(M) leaders like Kanti Ganguly or Subhash Chakraborty (both were long-serving ministers of the Left Front). Similar figures emerged in other districts, for example, Lakshman Seth (former MP) and Sushanta Ghosh (former MLA and district committee member) in East Midnapore, Dipak Sarkar (district committee member) in West Midnapore, Balai Sanpui (district committee member) and Suhrid Dutta (zonal committee secretary) in Hooghly, and so on. These people became the go-to men for the government for almost anything in their respective areas-law and order, agriculture, health, educational services, and industrialisation. The usual practice was to entrust them with the overall responsibility for any project; they would then involve the appropriate people/channels (local political leaders and cadres in the zonal and local committees and the panchayats) to carry out monitoring on a daily basis (see Banerjee 2010 for a discussion on the role of such party bosses). Formal administrative channels such as block development offices or local municipalities were completely subservient to the panchayats or the local committees.

The workings of this alternative bureaucracy were clearly evident in Singur. But surprisingly, a coherent narrative of its role never came to the forefront. Admittedly, the nature of the events easily lent themselves to a 'state versus peasants' format, but ignoring the political nuances leaves a void in understanding the layered nature of the party's role. In the following discussion, three interrelated themes-the choice of land, acquiring consent, and negotiating the transactions-are examined in order to build such an understanding. Each of these themes not only demonstrates the role of the CPI(M)'s alternative bureaucracy in Singur, but also provides an alternative narrative that shows how the notion of the formal 'state' and its development initiatives collapses as one approaches the grassroots. The events narrated next also have a larger resonance in the context of appropriation of land in South Asia, as they show how local political actors and priorities-employing techniques that can be often dubbed paralegal-subvert the very discourse of development that legitimises such appropriation by the 'state' in the first place.

\section{The narrative of land}

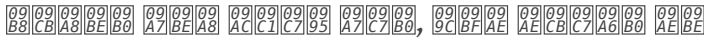

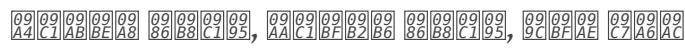

The land is our mother, harvesting golden crops.

Come storm, come police, we will not give our

(Text from a poster at Berabheri village, Singur) 
of the major questions that emerged as events at Singur unfurled (see Sarkar 2007) but was never satisfactorily answered-was: why choose such a fertile area for a project that requires large scale acquisition and transformation of agricultural land for industrial usage? Understandably, acquisition of some cultivated land was unavoidable, but the fact that the government completely ignored the fertility aspect is inexplicable. The Interim Report of the Citizens' Committee on Singur (2007) observed:

According to the Status Report issued by the CPM, most of the affected area is mono-cropped. They, however, seem to have used a land survey of the early seventies after which [...] soil fertility [has increased] enormously [...] most of the land is under four to five crops.

Nirupam Sen (senior CPI(M) leader and ex-industry minister) tries to explain the decision: We showed the TATA people several sites, but they chose Singur. Given the importance of the project, we saw no reason to disagree. The nature of the land was never taken into account. ${ }^{17}$

Given its location, ${ }^{18}$ Singur is a great site for entrepreneurial activity. However, it is surprising that land fertility was never a concern. In fact, Sen admits that they were unaware of it.

Singur was predominantly a low land, that is why almost all mouzas in the area have the suffix bheri in their names ${ }^{19}[. .$.$] in our records, most of the area remains sali$ (low yielding or single-crop), and only a small proportion is suna (high yielding or multi-crop). ${ }^{20}$

This admission does not explain why the government did not bother to verify its records before approving the project. What is even more perplexing is that in the face of widespread contrary reports in the media, the government stuck to its version. The following is an excerpt from a television interview with the Chief Minister Buddhadeb Bhattacharya, broadcast on 25 February 2007, almost ten months into the entire episode ( IBN Live 2007). ${ }^{21}$

Interviewer: So you [...] decided to give them [the TATAs] fertile land, knowing that it was the only way they would come to Kolkata?

Bhattacharya: No, no. What you are saying about the nature of the land [is not right]-maybe our reports are not up to date.

Interviewer: You concede that?

Bhattacharya: Yes. But I tell you that the major portion of the land is mono-crop. I stick to that. fertility levels (mono crop/unprofitable vs. multi crop/profitable) have rarely been questioned. But it is here that the role of the alternative bureaucracy lies. In the absence of land records, the government relied blindly on the party's local political managers for the necessary information. Bhattacharya categorically admits this in the interview:

Interviewer: If your report is not up to date, how can you say the major portion of land is mono-crop?

Bhattacharya: Then how can they [the citizens' committee] know that?

Interviewer: Because they visited it. They have spoken to the farmers.

Bhattacharya: I know these farmers better than them... My colleagues are working there, my party, my peasants' organisation knows better than these people. ${ }^{22}$

Evidently, Bhattacharya's source of information was his party. He precisely echoes the kind of information that was fed up the chain by the political managers at ground level. For example, Balai Sanpui, an influential local CPI(M) leader, said: 
This is predominantly a mono-crop area. The whole area is lowland. Out of the 997 acres, at most 100 acres are two-crop. Agriculture is hardly a profitable venture [...] not even 2000 rupees per bigha [is earned] annually. ${ }^{23}$

Contrast Sanpui's version with the following excerpt from Subrata Sinha's (ex-Deputy Director General, Geological Survey of India) observations:

The crème de la crème of this prime alluvial basin is the Hooghly river valley, capable of diversified multi-cropping the year round. This is because of rich alluviation during the monsoons, prolific groundwater and a network of stream channels. If cultivated with care, virtually every bit of its land is a veritable gold mine (Sinha 2008).

In Singur, farmers concurred with Sinha's observations. A woman, taking a break from sowing seeds in a plot adjacent to the factory walls, said:

We are now sowing dhan (paddy), next will be alu (potatoes). After alu, dhyarosh (okra), and then jhinga (ridge gourd). If time permits, we will grow alu again after jhinga. There are at least four crops per year. ${ }^{24}$

The overarching consensus among the locals was that they grew three to four crops on average. Krishnachandra Manna, a local farmer and ex-school teacher, gave an estimate entirely contradictory to Sanpui's claims:

Over the years with improved agricultural methods, four different crops per year is

a norm. On average, our annual net income was 12-13000 rupees per bigha. ${ }^{25}$

The most interesting comment came from Rathindra Ghosh, a farmer who now runs a small tea stall, having lost all his land (about 5 bighas). He accused the local party people of providing incorrect information to their political bosses, and claimed that neither the government nor the party authorities ever bothered to check with the locals.

No one came to us to enquire or discuss. The government asked their local committee workers, people like Balai Sanpui, Surhid Dutta. We know that they have misinformed the government. They said that not much rice grows here. That is a blatant lie. ${ }^{26}$

It is difficult to ascertain the purpose behind such deliberate misinformation, as the fertility level of Singur is not difficult to determine. Opposition quarters barraged the state with allegations and conspiracy theories. For example, it was said that: (1) the real intention behind the project was to recover lost political ground; (2) the demarcation of the factory site was a covert exercise to undermine the opposition stronghold by marking plots owned by TMC supporters for acquisition while leaving CPI(M) loyalists' land untouched, thus resulting in a zigzag shape instead of a conventional quadrangular area for the site; (3) contrary to the government's claim that TATA Motors' representatives chose the location, it was a local CPI(M) leader who informed the party that if the project were brought to Singur then local youth would rally behind the party in anticipation of employment, and their support could be used to regain the assembly seat, etc.

While there are is some anecdotal evidence in favour of these claims, it is difficult to ascertain its validity. Nonetheless, these stories do support the main argument: that right from the onset, not only were local CPI(M) leaders involved in the project, they were also the main ground-level facilitating agency entrusted by the government. Furthermore, such was the scale of this dependence that only information from party sources was considered reliable, even if there were contradictory reports elsewhere. This was the first instance of the alternative bureaucracy taking over-with the tacit support of the formal state-and underscores how the latter gradually retreated into its own shadow. The negotiation with the landowners to acquire consent forms the remainder of the story. 


\section{The narrative of consent and negotiation}

As events unfolded in Singur, so did
consent for acquisition. For example:

23 October 2006: Buddhadeb Bhattacharya announced that consent had been given for 800 acres ${ }^{27}$ and compensation had already been disbursed.

6 November 2006: Nirupam Sen said that consent had been given for 854 acres. $^{28}$

23 November 2006: Buddhadeb Bhattacharya announced the amount to be 913 acres.

As per the Status Report on Singur (WBIDC, 2006), by 2 December 2006 compensation had been awarded for only 635 acres, though the report also claimed that consent had been given for 952 acres.

9 January 2007: 789 farmers claimed that they had not given consent/taken compensation. The total amount of land owned by these farmers amounted to 337.97 acres. $^{29}$

Nirupam Sen admitted that consent was given for $70 \%$ of the area, and compensation had not been collected for the remaining portions. ${ }^{30}$ This estimate is closer to the above claim by the Krishijami Raksha Committee and contradicts the earlier announcements by Sen and Bhattacharya.

This idea of acquiring consent is rather intriguing. The Land Acquisition Act had no separate provision to acquire consent. However, of its own accord the government designed a consent form, promising an additional $10 \%$ to those who would sign within the deadline. ${ }^{31}$ The various consent estimates are based on these forms. The advantage of gathering consent was threefold: first, the government could claim that a large proportion of the farmers/sharecroppers supported the project and thereby readily agreed to sell their land; second, it also allowed the government (at least initially) to claim that the acquisition process and the compensation amount decided were just; and finally, a high proportion of 'consent givers' could be used as a political tool to undermine the opposition, accusing them of being anti-development.

During the course of this research, it gradually became clear that the actual exercise to garner consent was not just a case of collecting signatures, but a party-mediated exercise. The overt consensus at Singur among farmers who refused to give consent seems to be that from the announcement of the project to the specific decisions about which plots would be acquired, the party played a major role, with very limited negotiation with local people. The Interim Report of the Citizens' Committee's also concludes: 'Singur villagers learnt of the [...] acquisition [...] from newspapers, there being no Panchayat meeting or Party spokesman who informed them' (Citizens' Committee on Singur 2007).

Not only did the party play a crucial role in demarcating the plots for acquisition, it was also in charge of overseeing the list of farmers who would be eligible to receive compensation. The locals gave vivid examples of how the party controlled the entire process from the start. Rathindra Ghosh, (quoted earlier), recalled:

We were never officially informed about the acquisition. Notices were apparently put up in the block development office, but we had no idea. Once the details came out in the newspapers, we went to the office, and were straightaway told that our land has been earmarked for acquisition. There was no question of giving consent, nor did anybody discuss compensation adequacy. ${ }^{32}$

Krishnachandra Manna (quoted earlier) recalled a party meeting organised to discuss the project. 
The party called a meeting with all the farmers. We went, expecting information about the project and to negotiate compensation. Instead, they showed us a finalised map of the project site with the plots to be acquired already earmarked. Some of us protested, demanding a discussion before details were finalised. But the meeting was full of party cadres and our voices were drowned. We tried to argue that this was not the process, we could not just be ordered by the party, but in vain. Actually, the party knew discussions with the villagers might lead to many awkward questions. Instead, they planned to straightaway initiate the acquisition process, anticipating no further questions once compensation disbursement commences. ${ }^{33}$

What are these 'awkward questions' that Manna refers to? This is where the entire consent story comes in. Ratan Ghosh, a local TMC leader, elaborated:

We asked the CPI(M) leaders to call meetings with the villagers. Instead, they adopted a clandestine approach. For example, in place of registered sharecroppers, the party listed many names who were not even sharecroppers, but local cadres, or sharecroppers from other areas, even as far as [...] 10km from Singur. The party office even issued patta (ownership rights for vested plots) to their cadres for khas (non-vested) plots, who could then claim compensation. This also increased the number of people who could be shown to have given consent. They even managed to get some of their cadres to sign empty consent forms. ${ }^{34}$

Even if the majority of the above claims are dismissed as political blame-games, a farmer who did sell his land and claimed compensation and is also a CPI(M) supporter said (speaking strictly on condition of anonymity):

The government claims to have organised negotiation camps. True, there were camps, but by the party and for party members. The local leaders encouraged us (party supporters) to quickly sell our lands, and promised that we would be given something extra. We were also asked to convince other party supporters. No government official was present. The party may have also included some of its cadres' names-even though they were neither landowners nor sharecroppers-in the list of consent givers. ${ }^{35}$

Many versions of such stories can be heard in Singur, not only from dissenters, but also from estranged CPI(M) supporters. Balai Das, who used to be an active CPI(M) cadre until he refused to part with his land, asserted:

I was a CPI(M) supporter, a regular in party meetings and demonstrations. But I realised that only if one abides by what the leaders say, one can survive and be rewarded, but otherwise the party will coerce you into submission, even by brute force if necessary. That is what has happened to us because we refused to sell our land.

40 In an ethnographic account of Kadampur-another village in Singur-Dayabati Roy found a similar polarisation:

[A] section of people residing in Ghoshpara [...] offered their land [...] under the influence of $\mathrm{CPI}(\mathrm{M})[. .$.$] which could maintain its stronghold in that particular$ hamlet [...] The influence of the [...] party in the village was spread by some farmers [...] One of them, Karuna Das, a retired primary school teacher, is the present CPI (M) leader in the village and is organising people in favour of land acquisition [...]. He had been a panchayat member several times since 1978 and worked in the position of 'pradhan' (chief) and 'upapradhan' (deputy chief) (Roy 2007: 3324-25).

Interestingly, the claim that the entire ground level mobilisation at Singur was a partymediated exercise received support from local CPI(M) leaders as well. When asked to what extent the government depended on local party leaders, Balai Sanpui (local CPI(M) leader) not only admitted, but boasted, that he was one of the most reliable go-to men for Nirupam Sen. 
I used to talk directly with Nirupam babu. He instructed me to organise meetings and get the locals to agree. There were no officials here. We were in charge. Apart from me there were Srikanta Chatterjee (local committee member), Dipankar Das (district committee member) and Anil Basu (ex-MP). Everybody who wanted to sell their land used to come to us for advice. ${ }^{36}$

Sanpui even admitted, albeit indirectly, that they did not try to negotiate with the people who were known to oppose the project.

We did many meetings and explained the benefits of the project. But we used to avoid areas where they opposed it. What was the point? ${ }^{37}$

Finally, political managers like Sanpui were also the most reliable source for the higher authorities on the state of ground-level affairs, and even had a say in policy decisions. A very senior WBIDC official-who was an integral part of the project right from the onsetclearly voiced some of his concerns and suspicions:

I feel that local agents were pursuing their own political vendetta. We were extremely cautious, appreciating the emotional/psychological attachment of the villagers to their land, but the ground-level incidents were getting totally politicised, and unfortunately our political bosses would only listen to what their party people had to say. ${ }^{38}$

The point of recounting these stories is not to argue that the entire Singur project was an exercise in territorial subjugation by the CPI(M) under the garb of industrial development, but to highlight the presence of a certain degree of political control at the grassroots level by the alternative bureaucracy of the CPI(M), which has been largely missed by mainstream literature. Some of the major problems in Singur-particularly the lack of ground-level negotiation that led to much of the initial apprehension-stemmed from this. Owing to its partisan character and hegemonic tendencies, the alternative bureaucracy's attempt to facilitate the project remained parochial at best, never seriously engaging in consensus building. This trend was particularly apparent when many dissenters admitted that their initial opposition was actually a pressure tactic to force the government to increase the compensation amount. Even Ratan Ghosh, the local TMC leader, admitted:

If the government had increased the compensation amount, the opposition could not have cemented itself the way it eventually did. I saw many agitators convincing the farmers that the government would give in and raise prices if they could just hold on a little longer. ${ }^{39}$

A group of unwilling farmers at the forefront of the agitations openly stated (requesting not to be named):

Only later did the central demand of the agitation become the return of 400 acres. Initially we were protesting against the price, nobody in their right mind would have sold their land for such a meagre price, especially when their entire livelihood depended on that land. Had the government negotiated the price with us directly, none of this would have happened. But they relied on their local leaders, who in turn assumed that given their political clout in the area, convincing the farmers to sell their land at the pre-determined price will not pose much of a problem. So they did not even bother to talk to us, and convinced their supporters to sell their land first, promising additional benefits. By doing this, they managed to convince their political bosses that there was sufficient consensus, and acquisition would not be a problem. The government blindly trusted them, and was caught off-guard once the protests escalated. ${ }^{40}$

This is a fairly accurate summary of the fundamental conflicts at Singur. While the issue at stake was land price, the nature of the conflict was evidently political, the seeds of which were sown when the local party channels resorted to clandestine tactics to create a 
shroud of consensus around the project instead of recognising the legitimate concerns and aspirations of the stakeholders.

Such outcomes, however, are not surprising. These clandestine tactics reflect the same tendencies that the alternative bureaucratic channel had become so adept at executing. For decades it had perfected the art of manufacturing consent and extracting personal and/or localised political dividends out of all government initiatives, even resorting to violence if necessary. ${ }^{41}$ There were quite a few instances of police brutalities in Singur as well, particularly on 25 September and 2 December 2006. The Interim Report of the Citizens' Committee on Singur observed:

It is generally acknowledged that Singur villagers have not used violence [...] so far, even though there has been considerable violence by the police against villagers [...] especially on 25 September and 2 December [...] protestors are arrested for congregating, and ordinary vehicles are stopped and searched. Women were beaten up by male policemen, filthy language was used, villagers and student protestors lathi charged [...]. The charge of possession of dangerous weapons had been clapped on a two and a half year old girl who was sent to prison for several days (Citizens' Committee on Singur and Nandigram 2007).

Rajkumar Bhul, a 21-year-old farmer died in the violence of 25 September. Even more tragic is the case of Tapasi Malik, a young girl of 19, (allegedly) raped and brutally murdered. Her half-burnt body was found in the early hours of 18 December on the factory premises. ${ }^{42}$ In June 2007, Debu Malik (a local CPI(M) cadre) and Suhrid Dutta (the CPI(M) Singur zonal committee secretary) were arrested as the prime suspects in the case and three other local CPI(M) cadres-Mahadeb Santra, Subodh Kole and Dilip Malik-were also interrogated. ${ }^{43}$ The case is still on-going; Dutta was released on bail in 2009.

\section{Conclusion}

The combined narratives of land, consent, and negotiation bring certain dynamics that were at work in Singur-beyond the official ambit of the state-to the forefront. While the role of the state in the entire episode has been questioned repeatedly, it was the shadow state (conceptualised here as the alternative bureaucracy) that was all-pervasive on the ground. State institutions were barely present or functional, and much of the procedural inaccuracies were germane to how the state could influence the political managers that constituted the 'shadow' (or be influenced by them). In fact, these narratives show that within the imperatives brought by a strategy of industrial development, in reality the government had no choice but to depend on its trusted alternative bureaucratic structures, which kicked in not only to negotiate land ownership, determine price and usage patterns but also to encourage land invasion, exact electoral discipline and maintain political loyalties. Furthermore, the alternative bureaucracy had also become less attuned to the larger objectives of the government over time and had started to focus more on maximising localised political and even personal interests. The government, on the other hand, had become so dependent on the political managers for its administrative functions that it had no other way to counter such trends. ${ }^{44}$ The shadow state, evidently, 'exists at the most local level of all' (Harriss-White 2003: 83), as Singur, a story of peasant struggle, celebrated in the development-displacement tales of India, at some level becomes a story where the state was subsumed by its own shadow, forcing us to rethink the very idea of the 'state' in the context of land struggles in India. 


\section{BIBLIOGRAPHY}

Bandopadhyay, Debabrata (2006) 'Demise of an Ideology', Mainstream, 44(19), pp. 7-8.

Bandopadhyay, Debabrata (2007) Land, Labour and Governance, Kolkata: Worldview.

Bandyopadhyay, Partha Sarathi (2009) Ajker Paschimbanga: Kshamatar Rajniti, Janatar Rajniti, Calcutta: Aneek Publications.

Banerjee, Mukulika (2010) ‘A Left Front Election', in Anthony Heath \& Roger Jeffery (eds.), Diversity and Change in Modern India: Economic, Social and Political Approaches, Oxford \& New York: Oxford University Press/British Academy, pp. 243-66.

Banerjee, Mukulika (2010) 'Leadership and Political Work', in Pamela Price \& Arild Ruud (eds.), Power and Influence in India: Bosses, Lords, and Captains, New Delhi: Routledge, pp. 20-43.

Banerjee, Parthasarathi (2006) 'West Bengal: Land Acquisition and Peasant Resistance at Singur', Economic and Political Weekly, 41(16), pp. 4718-20.

Banerjee, Sumanta (2008) 'A Political Cul-de-sac: CPI(M)'s Tragic Denouement', Economic and Political Weekly, 43(42), pp. 12-15.

Banerjee, Sumanta (2006) 'Peasant Hares and Capitalist Hounds of Singur', Economic and Political Weekly, 41(52), pp. 5296-98.

Banerjee, Abhijit Vinayak; Bardhan, Pranab; Basu, Kaushik; Datta Chaudhury, Mrinal; Ghatak, Maitreesh; Guha, Ashok Sanjay; Majumdar, Mukul; Mookherjee, Dilip; Ray, Debraj (2007) ‘Beyond Nandigram: Industrialisation in West Bengal', Economic and Political Weekly, 42(17), pp. 1487-89.

Banerjee-Guha, Swapna (2008) 'Space Relations of Capital and Significance of New Economic Enclaves: SEZs in India', Economic and Political Weekly, 43(47), pp. 51-59.

Bhaduri, Amit (2007) 'Development or Development Terrorism', Economic and Political Weekly, 42 (7), pp. 552-53.

Bhattacharyya, Dwaipayan (2010) 'Left in the Lurch: The Demise of the World's Longest Elected Regime', Economic and Political Weekly, 45(3), pp. 51-59.

Bhattacharyya, Dwaipayan (2009) 'Of Control and Factions: The Changing 'Party-Society' in Rural West Bengal', Economic and Political Weekly, 44(9), pp. 59-69.

Bhattacharyya, Dwaipayan (2001) “"Civic Community” and Its Margins: School Teachers in Rural West Bengal', Economic and Political Weekly, 36(8), pp. 673-83.

Bhattacharyya, Harihar (1998) Micro-Foundations of Bengal Communism, New Delhi: Ajanta Books International.

Bhattacharya, Malini (2007) 'Nandigram and the Question of Development', Economic and Political Weekly, 42(21), pp. 1895-99.

Bourdieu Pierre; Boltanski Luc; Maldidier Pascale (1971) 'La défense du corps', Social Science Information, 10, pp. 45-86. 
Chakravarty, Deepita; Bose, Indranil (2013) 'Industrialising West Bengal: The Case of Institutional Stickiness', in Kunal Sen (ed.), State Business Relations and Economic Development in Africa and India, London: Routledge, pp. 181-97.

Chandra, Nirmal Kumar (2008) 'TATA Motors in Singur: A Step Towards Industrialisation or Pauperisation?', Economic and Political Weekly, 43(50), pp. 36-51.

Citizens' Committee on Singur and Nandigram (2007) Interim Report of the Citizens' Committee on Singur and Nandigram, URL: http://singur-singur.blogspot.co.uk/2007/03/interim-report-ofcitizens-committee-on.html.

Dasgupta, Sreemanta (1998) 'West Bengal and Industry: A Regional Perspective', Economic and Political Weekly, 33(47-48), pp. 3049-60.

Harriss-White, Barbara (2003) India Working: Essays on Society and Economy, Cambridge: Cambridge University Press.

Harvey, David (2005) The New Imperialism, Oxford: Oxford University Press.

Herring, Ronald J. (1999) 'Embedded Particularism: India's Failed Development State', in Meredith Woo-Cumings (ed.), The Developmental State, Ithaca \& New York: Cornell University Press, pp. 306-34.

Jenkins, Rob; Kenndey, Lorraine; Mukhopadhyay, Partha (2014) Power, Policy, and Protest: The Politics of India's Special Economic Zones, New Delhi: Oxford University Press.

Kohli, Atul (1990) Democracy and Discontent: India's Growing Crisis of Governability, Cambridge: Cambridge University Press.

Kohli, Atul (1987) The State and Poverty in India: The Politics of Reform, New York: Cambridge University Press.

Mohanty, Mritiunjoy (2007) 'Singur and the Political Economy of Structural Change', Indian Institute of Management Working Paper Series, 601, Calcutta, URL: http://www.macroscan.org/pol/ feb07/pol170207Singur.htm.

Mukharji, Projit Bihari (2009) “"Communist” Dispossession Meets "Reactionary” Resistance: The Ironies of the Parliamentary Left in West-Bengal', Focaal - European Journal of Anthropology, 54, pp. 89-96.

Namboodiri, Udayan (2006) Bengal's Night without End, New Delhi: India First Foundation.

Nielsen, Kenneth Bo (2010) ‘Contesting India’s Development? Industrialisation, Land Acquisition and Protest in West Bengal', Forum for Development Studies, 37(2), pp. 145-70.

Patnaik, Prabhat (2007): 'In the Aftermath of Nandigram', Economic and Political Weekly, 42(21), pp. 1893-95.

Roy, Ananya (2009) 'Why India Cannot Plan its Cities: Informality, Insurgence and the Idiom of Urbanisation', Planning Theory, 8(1), pp. 76-87.

Roy, Ananya (2005) ‘Urban Informality: Towards an Epistemology of Planning', Journal of the American Association of Planning, 71(2), pp. 147-58.

Roy, Ananya (2004) 'The Gentleman's City: Urban Informality in the Calcutta of New Communism', in Ananya Roy \& Nezar Alsayyad (eds.) Urban Informality: Transnational Perspectives from the Middle East, Latin America, and South Asia, Lanham (Maryland): Lexington Books, pp. 14770. 
Roy, Ananya (2002) City Requiem, Calcutta: Gender and the Politics of Poverty, Minneapolis: University of Minnesota Press.

Roy, Dayabati (2007) 'Politics at the Margin: A Tale of Two Villages', Economic and Political Weekly, 42(32), pp. 3323-29.

Ruud, Arild Engelsen (1994) 'Land and Power: The Marxist Conquest of Rural Bengal', Modern Asian Studies, 28(2), pp. 357-80.

Sarkar, Abhirup (2007) 'Development and Displacement: The Story of Land Acquisition in West Bengal', Economic and Political Weekly, 42(16), pp. 1435-42.

Sarkar, Abhirup (2006) 'Political Economy of West Bengal: A Puzzle and a Hypothesis', Economic and Political Weekly 41(4), pp. 341-48.

Sarkar, Tanika; Chowdhury, Sumit (2009) 'The Meaning of Nandigram: Corporate Land Invasion, People's Power, and the Left in India', Focaal - European Journal of Anthropology, 54, pp. 73-88.

Sau, Ranjit (2008) 'A Ballad of Singur: Progress with Human Dignity', Economic and Political Weekly, 43(43), pp. 10-13.

Sinha, Subrata (2008) ‘Singur-Sowing Problems', Mainstream, 46(31), URL: http:// www.mainstreamweekly.net/article919.html.

Sinha, Aseema (2004) 'Ideas, Interests and Institutions in Policy Change: A Comparison of West Bengal and Gujarat', in Rob Jenkins (ed.), Regional Reflections: Comparing Politics Across India's States: Case Studies of Democracy in Practice, New Delhi: Oxford University Press, pp. 66-106.

Steur, Luisa; Das, Ritanjan (2009) 'What's Left? Land Expropriation, Socialist "Modernizers", and Peasant Resistance in Asia', Focaal - European Journal of Anthropology, 54, pp. 67-72.

WBIDC West Bengal Industrial Development Corporation (2006) Status Report on Singur, Calcutta: Government of West Bengal.

\section{NOTES}

1. Ramanathan, Usha (2006) 'Creating Dispensable Citizens' The Hindu, 14 April, URL: http:// www.thehindu.com/todays-paper/tp-opinion/article3147114.ece.

2. The CPI(M) alone won 176 seats (37.13\% vote share), the highest since 1991.

3. Alongside Singur, a significant incident took place in Nandigram, another cluster of villages in the East Midnapore district. The locals had been protesting since January 2007 against a proposal to acquire land for a chemical hub. On 14 March, 14 people were killed and hundreds injured in an indiscriminate police action, as the state government (allegedly) let loose armed party cadres alongside police forces, who engaged in indiscriminate violence (Sarkar \& Chowdhury 2009). In common parlance, Singur-Nandigram are mentioned together, with Nandigram equally evocative in public perception. However, for analytical clarity, this paper focuses on Singur alone.

4. The CPI(M)'s seat share reduced to 40 (30.08\% vote share).

5. And also elsewhere, for example, in Sierra Leone in the context of civil war (see Herring 1999).

6. The doctoral research itself focused on the politics of policy transition in West Bengal as engineered by the Left Front since the early 1990s. It involved a wide variety of methods: archival research, about 100 qualitative interviews, and the ethnographic study at Singur. During the ethnography, people from all walks of life were interacted with, such as, local CPI(M) cadres/ supporters, the local BDO (block development officer) and panchayat pradhan (the panchayat head), farmers who sold their land and received compensation and those who opposed the 
acquisition, sharecroppers affected in the process, villagers injured in clashes with the police, and so on. While it is not possible to elaborate on the research design process here, it is nonetheless relevant to point out that at the onset of the ethnography, the concept of the 'shadow' was not envisaged to emerge as strongly as it eventually did. The initial interactions with the villagers were mostly based on their experience of the acquisition 'process'. It was only after a few months in the field-and having established a trust base so they started talking about the underlying politics-that the idea of using the shadow state as a conceptual framework eventually took root.

7. See, for example, Sarkar and Chowdhury (2009), Sarkar (2007), Bandopadhyay (2007), and P. Banerjee (2006) for discussions of various perspectives on land struggles, but with the implicit assumption of an 'official' state with statutory responsibilities.

8. Between 1977 and 1990, West Bengal's share in gross national output declined from an already low $10.5 \%$ to a paltry $6.1 \%$. (source: Annual Survey of Industries, GoI, 1977-1992).

9. Between 1991 and 2003 West Bengal's share of all-India industrial proposals was only $4.73 \%$, and the actual investment was $3.85 \%$ of all-India investment. For a state like Maharashtra, these figures were $19.9 \%$ and $21.11 \%$ respectively (Sinha 2004 ).

10. In 2001, the CPI(M) won 143 seats (36.6\% vote share), and 176 seats (37.13\% vote share) in 2006.

11. Approximately $\$ 1500$ in the current exchange rate.

12. A mouza corresponds to a specific land area within which there may be one or more settlements, still used for land revenue administration.

13. Trinamool Congress: the main opposition party in West Bengal at the time, and currently in government. TMC came to power in 2011, and while it is not within the purview of this paper to trace these subsequent developments in West Bengal, the growth and operational style of the TMC reinforces the conceptualisation of the 'shadow state' in the state's socio-political environment.

14. This is a commonly known phenomenon in West Bengal; see Bandyopadhyay (2009) and Roy (2002) for detailed descriptions.

15. See Bhattacharyya (1998) for a detailed discussion.

16. 'It's Now or Never' (2001), 25 May, URL: http://www.thestatesman.net/index.php? option=com_content\&view=article\&show=archive\&id=26739\&catid=39\&year=2001\&month=5\&day=25\&Itemid=66

17. Interview by author, Kolkata, 22 September 2009.

18. Singur is located adjacent to National Highway 2, with easy access to Kolkata.

19. Bheri means 'low-land'. So the names Singher-bheri, Bera-bheri, etc. imply that these were once low lands. Being water logged most of the time, such low lands were hardly suitable for cultivation.

20. Interview by author, Kolkata, 22 September 2009.

21. 'Devil's Advocate', 25 February, URL: http://ibnlive.in.com/news/devils-advocatebuddhadeb/34441-1-p2.html.

22. An interesting parallel can be drawn between such symbolic power of party networks and Bourdieu and Boltanski's notion of 'multipositionality' (1971).

23. Interview by author, Singur, 23 September 2009. Bigha is a land measurement unit widely used in India. One bigha = one-third of an acre or 1337.9 square meters of land (approximately).

24. Interview by author, Singur, 1 September 2009.

25. Interview by author, Singur, 1 September 2009.

26. Interview by author, Singur, 23 September 2009.

27. Anandabazar Patrika 2006, 24 October. Status of the Singur Project.

28. Anandabazar Patrika (2006), 3 November. Adequate Consent among Singur Farmers. 
29. Source: List of peasants unwilling to sell their land (based on the affidavits of their statements), prepared by Singur Krishijami Raksha Committee.

30. Interview by author, Kolkata, 22 September 2009.

31. This decision was questioned by the Kolkata High Court. See The Telegraph (2007), 24 February. HC Seeks Singur Explanation.

32. Interview by author, Singur, 23 September 2009.

33. Interview by author, Singur, 1 September 2009.

34. Interview by author, Singur, 23 September 2009.

35. Interview by author, Singur, 23 September 2009.

36. Interview by author, Singur, 23 September 2009.

37. Interview by author, Singur, 23 September 2009.

38. Interview by author, Kolkata, 29 August, 21 and 28 September 2009. Anonymity requested.

39. Interview by author, Singur, 23 September 2009.

40. Interview by author, Singur, 1 September 2009.

41. See Namboodiri (2006) for details.

42. The Telegraph (2006), 19 December. Throttled, Dumped, Burnt, report by Kinsuk Basu.

43. The Telegraph (2007), 29 June, Singur Enforcer in Dock: CPIM Leader Held for Murder, Bureau Report; and 30 June, Lackey Sings, Leader Faces Test, Bureau Report.

44. Although beyond the ambit of this paper, a different point can be extrapolated from this observation. The 'shadow state' in West Bengal went much beyond the land struggles in Singur and elsewhere, and naturally played a crucial role in maintaining the political as well as the moral hegemony of the CPI(M), particularly in the countryside. Its role in exacting electoral discipline in the early/mid part of the Left Front rule, and the part it played in the last few years of the Front, deserve special attention, and could be a future research project in itself.

\section{ABSTRACTS}

India's rapid economic growth has frequently been marred by struggles over land acquisition and displacement. This paper re-examines one such case. In 2006, protests erupted in Singur (a small cluster of villages in West Bengal) against government initiatives to acquire land for a private industrial project. The protests gathered enough momentum to stall the project, and went on to have a decisive impact on the electoral fortunes of the government, thus attaining a cult status in the country's development-displacement narratives. This paper presents the Singur story in a new light, arguing that there was a political character to the entire episode, largely ignored by mainstream literature. Based on the idea of the 'shadow-state' (Harriss-White 2003), the paper examines the role played by the political managers of the ruling Communist Party of India (Marxist)-CPI(M)-and highlights three themes-choice of land, acquiring consent, and negotiation-to build its narrative.

INDEX

Keywords: Singur, West Bengal, CPI(M), land acquisition, shadow-state 
AUTHOR

RITANJAN DAS

University of Portsmouth 